Educational Research for Social Change (ERSC)

Volume 10 No. 1 April 2021

pp. $83-100$

ersc.nmmu.ac.za

ISSN: 2221-4070

\title{
Enhancing the Management Performance of Departmental Heads in Primary and Secondary Schools: PAR as a Practice-Enhancing Process $^{1}$
}

\author{
Veli Nhlapo \\ ORCID No: http://orcid.org/0000-0003-0931-3911 \\ Independent Researcher \\ velinhlapo995@gmail.com
}

\begin{abstract}
The aim of this paper is to explain how participatory action research can be used to enhance the management competence of departmental heads (DHs) at primary and secondary schools. Research to improve the managerial performance of $\mathrm{DHs}$ tends to be steeped in a traditional mode of inquiry that merely highlights the challenges and makes recommendations in the hope that $\mathrm{DHs}$ will implement them. Teacher workshops aimed at improving their managerial capacity are often too theoretical and general, positioning teachers as passive recipients of knowledge rather than as active contributors. Departmental heads, like all teachers, should be viewed as professionals capable of overcoming their own challenges. In this study, engaging $\mathrm{DH}$ in participatory action research allowed for the development of a participatory strategy to improve their performance as managers. The evidence presented here highlights the ontological and epistemological potency of participatory action research as a practice-enhancing process.
\end{abstract}

Keywords: departmental heads, participatory action research, critical emancipatory paradigm, social justice

Copyright: (C) 2021 Nhlapo

This is an open access article distributed under the terms of the Creative Commons Attribution NonCommercial License, which permits unrestricted non-commercial use, distribution, and reproduction in any medium, provided the original author and source are credited.

Please reference as: Nhlapo, V. (2021). Enhancing the Management Performance of Departmental Heads in Primary and Secondary Schools: PAR as a Practice-Enhancing Process. Educational Research for Social Change, 10 (1), 83-100. http://dx.doi.org/10.17159/2221-4070/2021/v10i1a6

\section{Introduction}

The aim of this paper is to explain how participatory action research (PAR) enabled departmental heads (DHs) to enhance their management performance. DHs are seen as the weakest link in schools (Nhlapo,

\footnotetext{
${ }^{1}$ Ethical clearance number: UFS-EDU-2011-0062
} 
2014) because, as teachers, they do not usually possess the managerial competences required of their positions.

Studies on DHs tend to be steeped in a traditional mode of inquiry that raises issues and makes recommendations in the hope that these recommendations will be implemented (Malloy, 2017; Nhlapo, 2014). Despite these research efforts, DHs continue to grapple with challenges relating to their managerial tasks such as planning, communication, monitoring, time management, conducting meetings, and holding teachers accountable for their work. Furthermore, workshops aimed at improving the managerial capacity of $\mathrm{DHs}$ are often too theoretical and general, positioning them as passive recipients of knowledge rather than as active contributors (Wessels \& Wood, 2019). DHs, like all teachers, should be viewed as professionals capable of overcoming their own challenges (Nhlapo, 2014).

I had identified the need for a democratic and action-oriented approach that would fully involve DHs in their own professional development and therefore adopted a PAR study (Nhlapo, 2014) because it is transformation-orientated and grounded in an emancipatory agenda. In addition to DHs, principals, deputy principals, members of school governing bodies (SGBs), and community development workers participated in this qualitative study. They were included because of the need for the broadest possible range of experiences, knowledge, and insights, and to provide additional support to implement the learning of DHs. Acting as a diversity of coresearchers, they brought multiple rich perspectives to bear on discussions, and generated innovative ideas and solutions (Cho, 2013).

Below, I first discuss action learning as the theoretical framework for my study and then I explicate the methodology, before discussing the findings and their implications for the professional development of DHs.

\section{Theoretical Framework}

Action learning $(A L)$ is an established tool in management education for enhancing managerial competence (Kelliher \& Byrne, 2018), and was originated by Reg Revans (as noted in Kemmis et al., 2014). It is an intervention that fosters collaborative professional and peer learning, as well as problem sharing (Boonyuen et al., 2016). AL recognises practitioners as both sources of knowledge and users of knowledge to generate new ideas and practices, and is premised on the idea that DHs can learn effectively with, and from, other DHs. Furthermore, it suggests that people can identify and resolve their own challenges when provided with the opportunities and structures to share their knowledge and expertise, and to critically reflect on their practice. AL assumes that "there is no learning without action and no action without learning" (Revans, 2011, p. 85). According to Boonyuen et al. (2016), AL encompasses

learning and creating knowledge through concrete experience, experimenting, observing and identifying the problem, reflecting on this experience, experimenting, analyzing and forming generalizations from experiments, planning solutions, testing the implications in new experiences, and beginning the process again. ( $p .3$ )

In summary, AL entails learning from action and experience and, moreover, taking action as a result of this learning (Marquardt \& Banks, 2010). It can therefore be argued that DHs should immerse themselves in action in order to learn. The process of AL involves small groups working and acting on real problems and learning as individuals, as a team, and as an organisation. In recognising that $A L$ is contextual, it is important for participants to "experience action and learning in their own environment" (Kelliher \& Byrne, 2018, p. 37). 
Cho and Bong (2013) condensed the AL process into the following phases: preparation, team meetings, and follow-up activities. During preparation, people who are targeted are mobilised prior to launching an AL project. As part of the preparation process, an orientation session is held to expose the participants to the intricacies of AL. Cho (2013) pointed out that people who are mobilised should be organised into a structure to engender trust and rapport among them. The participants should be grouped into sets of 4-8 persons (Boonyuen et al., 2016).

Each set of participants, led by a facilitator, converges regularly to share and identify challenges, reflect, form new learning, and develop action plans for solutions. These team meetings are important because AL projects are work-based and difficult to tackle alone (Revans, 2011). Furthermore, reflection during these meetings is critical for balancing action and learning during AL (Cho \& Egan, 2010). Reynolds (2011) averred that reflection strengthens action and learning, and creates learning that is anchored in past and current experiences.

Follow-up activities, where participants share their solutions and the lessons accrued from the AL process, take place after reflection. Most follow-up activities take the form of face-to-face meetings (Cho, 2013). Thornton and Yoong (2011) claimed that the blending of online and face-to-face meetings is gaining currency as an attempt to obviate time and space limitations.

An effectively executed AL process may spawn several benefits such as leadership skills (Marquardt \& Banks, 2010) and empowerment (Van Der Voort \& Wood, 2014; 2016). The process can last from one month up to one and a half years (Boonyuen et al., 2016).

\section{Methodology}

The paradigm underlying this study was critical emancipatory research (CER), a strand of research within critical theory. As Asghar (2013) noted, critical theory is a potentially impactful social philosophy. The ontological orientation of CER is historical realism (Fard, 2012; Kivunja \& Kuyini, 2017; Makombe, 2017), which maintains that reality is shaped over time by social, political, cultural, economic, ethnic, and gender factors (Rehman \& Alharthi, 2016).

CER calls for an approach that is dialogic and dialectical. Accordingly, this study operationalised the principles of CER through a participatory action research (PAR) design. Similarly, Jordan (2008) affirmed that PAR is based in a critical emancipatory paradigm. PAR, which has its roots in the work of Freire (1993), calls for the engagement of those who are being researched, such that research participants become coresearchers (Carr \& Kemmis, 1986). Therefore, my coresearchers and I shared a communicative space in which we jointly and critically reflected on issues to effect social transformation (Kemmis et al., 2014).

Epistemologically, CER is transactional and subjectivist (Fard, 2012; Kivunja \& Kuyini, 2017; Makombe, 2017). Therefore, the researcher and coresearchers within this paradigm are inextricably linked by way of the values and biases that they bring to a study. This implies that the researcher's and coresearchers' standpoints influence knowledge generation (Cameron \& Singh, 2013).

Given that PAR fosters a joint process of knowledge production that spawns new insights for participants (Bergold \& Thomas, 2012), it enacts an emancipatory agenda by dismantling, disrupting, and subverting power differentials. Through PAR, challenges were identified, the best course of action was chosen, the chosen course of action implemented, and the next course of action agreed uponfollowed by critical reflection and evaluation (Wood \& Zuber-Skerritt, 2013). 
The challenges facing the DHs were collectively identified during Session 3 by means of a SWOT analysis (all sessions are discussed and detailed further on, in the Findings section and Table 2). The SWOT analysis revealed that the DHs have several challenges, however, of these they prioritised planning, meetings, monitoring, communication, and accountability. Decisions were taken on the course of action with which to deal with these challenges. In this regard, the DHs were trained through a series of workshop sessions on how to plan (Session 4), the types of meetings, including their standing agenda items (Session 5), how to monitor, what to monitor, and when to monitor (Session 6), and accountability (Session 7). The DHs then returned to their respective schools to implement what they had learned during the workshops, and refined their practice in line with the unique circumstances of their schools.

The participants came from four primary schools and two secondary schools in the Setsoto local municipality in the Free State province (see Table 1). Participants were identified through purposive and snowball sampling (Johnson \& Christensen, 2014). The cumulative effect of the three sampling techniques was the assembling of a diverse team, with vast and wide-ranging experience, whose participation enriched the study.

Table 1

Participant Profile

\begin{tabular}{lcccccc}
\hline \multirow{2}{*}{ Participants } & \multicolumn{2}{c}{ School Type } & \multicolumn{2}{c}{ Gender } & \multirow{2}{*}{ Total } \\
\cline { 2 - 5 } & Primary & Secondary & Male & Female & \\
\hline Departmental heads & 7 & 9 & 9 & 7 & 16 \\
\hline Principals & 2 & 1 & 2 & 1 & 3 \\
\hline Deputy principals & 1 & 1 & 1 & 1 & 2 \\
\hline SGB members & 4 & 5 & 4 & 5 & 9 \\
\hline Teacher union representatives & 1 & 2 & 1 & 2 & 3 \\
\hline $\begin{array}{l}\text { Community development } \\
\text { workers }\end{array}$ & & & 1 & 0 & 1 \\
\hline TOTAL & 15 & 18 & 18 & 16 & 34 \\
\hline
\end{tabular}

Data were generated through dialogue within the group, which was facilitated using the free attitude interview (FAI) method developed by Buskens (2011). FAl resonates with the emancipatory ideals of CER and PAR, namely, freedom, respect, hope, equality, justice, and transformation. The use of this method also helped to diffuse the power differentials within the group. I assumed the role of the facilitator to generate knowledge through dialogue. Data were also generated from artefacts, reflections, written testimonies from participating schools, a SWOT analysis, and a priority list.

I took four discernible steps when implementing the FAl method. Firstly, I, as the facilitator, asked exploring questions (Buskens, 2011). These were open-ended questions that encouraged the coresearchers to explore ideas and opinions. Secondly, I offered a reflective summary in which I repeated the opinions and sentiments of the coresearchers in my own words. I used the reflective summary to (i) order and structure the coresearchers' information, (ii) ascertain whether I had correctly understood what the coresearchers had said, and (iii) encourage the coresearchers to share more information. Thirdly, I posed a clarifying question in instances where the coresearchers' views were unclear or ambiguous. Lastly, I captured the coresearchers' salient and pertinent opinions, views, and sentiments in a final summary.

I transcribed the recorded discussions immediately after each scheduled meeting while everything was still fresh in my mind. This minimised the potential loss or distortion of data. The transcribed text 
became the embodiment or record of the communication event wherein facts, opinions, beliefs, and sentiments were formally presented. I then analysed the data at three levels, according to the threedimensional critical discourse analysis (CDA) framework (Van Dijk, 2006). During micro-level analysis, I interrogated the literal meaning of the FAI transcript to determine what the coresearchers had said. During meso-level analysis, I examined the discursive practices (or culture) of the coresearchers. Discursive practices informed how the coresearchers thought, acted, and spoke. Finally, during macrolevel analysis, the social, political, and other contexts in which the coresearchers made statements were exposed. In so doing, this exposure laid bare any traces of power abuse, domination, and inequality. Importantly, CDA problematises power and is committed to disrupting it and was thus privileged for use in this study because of its compatibility with CER and PAR principles.

On the other hand, integrity in this study was couched in the five validities championed by Herr and Anderson (2015). Outcome validity refers to the extent to which the outcomes of a study are successful. This study, true to its aim, yielded an effective strategy that enhanced the management performance of the participating DHs. Process validity is concerned with the effectiveness of an approach in resolving a research problem. Through PAR, the self-identified inadequacies of the DHs were ameliorated. Democratic validity focuses on the extent to which a research enterprise is carried out in collaboration with the people who are affected by the problem under scrutiny. DHs, as coresearchers, were actively involved in the study from conception to conclusion. Catalytic validity concerns itself with the extent to which a study transforms the participants, deepens their understanding, and motivates them to take further action beyond the scope of the study. For example, nine DHs established professional learning communities in their schools as a result of their participation in this study. Lastly, dialogic validity is concerned with the subjection of a study to critical and reflective dialogue. The study was presented as a work in progress at provincial colloquia and national conferences in South Africa where it was constructively critiqued. The various inputs provided at the conferences contributed significantly to the overall quality of the study.

The study received ethical clearance (UFS-EDU-2011-0062) from the University of the Free State, which attests to its adherence to ethical principles of informed consent, confidentiality, anonymity, autonomy, protection from physical harm, and beneficence.

\section{Limitations}

The first limitation of this study was the issue of power differentials amongst participants. While we worked hard to foster equitable relationships, we acknowledged at the same time the possibility of there being power imbalances during the inquiry. Self-reflexivity was thus used to mitigate the threat posed by power differentials, ensuring that we "articulate[d] our value systems, our multiple identities and locations of power and privilege, and how these understandings [might] influence our interactions with others and our research practice" (Brydon-Miller, 2013 p. 204). Therefore, each participant was allocated two minutes to articulate their values and biases during the first session.

The second limitation involved the unequal participation of group members. Certain people are naturally reticent and reserved, which can lead to more outspoken individuals monopolising the communicative space. To obviate this risk and maximise the participation of all members of the research group, we used participatory strategies to determine the management priorities to discuss. Furthermore, members were encouraged to converse in any language they were comfortable with.

To further mitigate the risk of unequal participation, at the beginning of the study, the research group adopted rules of engagement that which were based on the following values: equality; human dignity; freedom and security of person; freedom of religion, belief, and opinion; freedom of expression; and, freedom of language and culture. This shared set of values helped to bring about a spirit of inclusion 
within the group. Moreover, I exposed the research group to Yosso's (2005) concept of community cultural wealth. This concept allowed SGB members to see themselves as repositories of irreplaceable knowledge and, therefore, as valuable members of the research group.

Finally, time constraints posed a threat to the study. Research group members were all busy people with multiple commitments that competed for their time. To ensure that neither the study nor the participants' private or official engagements suffered, we drew up an implementation plan to guide the study, for the purpose of time management.

\section{Discussion of Findings}

This PAR study aimed to collaboratively develop a process for enhancing the management competence of DHs. Table 2 below captures the process that was followed to do so. After determining the learning needs in Session 3, a workshop was developed to help DHs learn to improve a specific skill. They then returned to their schools and implemented their learning and reflected on their experiences at their next workshop. While I delivered the workshops based on the participants' learning needs, they were intentionally interactive and dialogue-based. 
Table 2

Research Process

\begin{tabular}{|c|c|c|c|}
\hline Session & $\begin{array}{l}\text { Time } \\
\text { frame }\end{array}$ & Objective(s) for session & Data documentation \\
\hline 1. & $\begin{array}{l}14: 00- \\
16: 00\end{array}$ & $\begin{array}{l}\text { - } \text { Purpose of research } \\
\text { - Getting to know one another } \\
\text { - Rules of engagement }\end{array}$ & $\begin{array}{l}\text { Conversations audiotape, } \\
\text { transcribed after each } \\
\text { meeting } \\
\text { - } \text { Artefacts generated in }\end{array}$ \\
\hline 2. & & - Workshop 1: PAR principles. & $\begin{array}{l}\text { group and workshops such } \\
\text { as SWOT analysis, priority }\end{array}$ \\
\hline 3. & & $\begin{array}{l}\text { - SWOT analysis of DH } \\
\text { competencies } \\
\text { - Drawing up a priority list for } \\
\text { action: DH learning needs }\end{array}$ & $\begin{array}{ll} & \text { lists } \\
\text { - } & \text { Reflections } \\
\text { - } & \text { Written testimonies from } \\
& \text { participating schools }\end{array}$ \\
\hline 4. & & - Workshop 2: Planning skills & \\
\hline 5. & & $\begin{array}{l}\text { Reflection on implementation } \\
\text { of planning skills } \\
\text { - Workshop 3: Meetings and } \\
\text { communication skills }\end{array}$ & \\
\hline 6. & & $\begin{array}{l}\text { Reflection on implementation } \\
\text { of meetings and } \\
\text { communication skills } \\
\text { Workshop 4: Monitoring of } \\
\text { teachers' and learners' work }\end{array}$ & \\
\hline 7. & & $\begin{array}{l}\text { Reflection on implementation } \\
\text { of monitoring teachers' and } \\
\text { learners' work } \\
\text { - Workshop 5: How to hold } \\
\text { teachers accountable for their } \\
\text { work performance }\end{array}$ & \\
\hline 8. & & $\begin{array}{l}\text { Reflection on implementation } \\
\text { of holding teachers } \\
\text { accountable for their work } \\
\text { performance } \\
\text { Reflection on impact: Evidence } \\
\text { regarding change in practice } \\
\text { from participants at each } \\
\text { school } \\
\text { Reach consensus on the } \\
\text { dissemination of findings }\end{array}$ & \\
\hline
\end{tabular}

Notes: After each workshop, the DHs went back to their respective schools to implement what they had learned. Sessions 1-8 were held at participating schools on a rotational basis. Each session started with an icebreaker activity and the participants reflected on their experiences.

It is imperative to note that the aim of this paper is not to present evidence of the improved practices of the DHs, but to show the benefits of the PAR process for the professional development of DHs. I now discuss the features of this process. 


\section{The Importance of Mobilising Participants}

PAR begins with the identification of a problem and, thereafter, people who experience that problem are mobilised to solve it (Eruera, 2010). Mobilisation is an intervention tool that envisages social change (Tedrow et al., 2012). The following excerpts from a conversation within the research group testify to the link between mobilisation and social change:

I am grateful to the researcher for going out of his way to approach us as key leaders in our community to participate in this endeavour. We thank you for drawing to our attention the challenges in our schools. Here I am in the midst of individuals who are committed to helping departmental heads to perform better. We are all looking forward to learning a lot in the process. (Deputy principal, p. 20)

Thanks for inviting us to participate in this groundbreaking project. Together we will help our departmental heads to overcome their challenges. Empowering them will lead to the transformation of our local schools. (SGB, p. 27)

Explicit in these excerpts is the community's concern about the plight of DHs. According to Lippman (2013), shared concern is one of the principal domains of community mobilisation. The shared concern of the research group stemmed from members' awareness of the problem at hand, which drove them to take charge of their affairs by collectively finding solutions to their problems. Tedrow et al. (2012) agreed that mobilisation should give rise to awareness and empower communities to confront their issues by engaging in collective processes. For this study, mobilisation sought to facilitate collaboration between DHs and the school community through activities aimed at building DHs' capacity through their own agency. Agency, empowerment, capacity building, and participation are the pillars of mobilisation (Campbell, 2014) that can create a conducive, supportive environment for the DHs.

\section{Assembling a Diverse Research Group}

There is mounting support for using teamwork to deal with organisational challenges (McEvoy et al., 2019; Nhlapo, 2014). Dworski-Riggs and Langehout (2010) advised that people who have been mobilised should be organised into a team structure. In this study, the research group was drawn from diverse backgrounds and this diversity contributed to the efficacy of the team, as these excerpts illustrate:

I believe in partnerships and teamwork. I have seen people coming together and jointly overcoming insurmountable problems. The collective wisdom of this team meeting here will unlock the challenges facing the departmental heads. (SGB, p. 32)

I am excited to have been part of this team that has principals, deputy principals, HODs [DHs], members of school governing bodies, parents-oh wait, and a community development worker. Pardon me, almost forgot our circuit manager and teacher unions, from whom we learned so much. You will agree with me when I say that the success of this coming-together was largely through your different backgrounds and experiences and the deep conversations. We started and finished this task. Coming up with solutions was a walk in the park. Unity was our strength. We know why this great team came together. (DH, p. 16)

The research group was able to solve problems and make informed decisions because of - not in spite of-inter-member differences. Benedict (2016) concurred that it is the heterogeneity of teams that enables them to make high-quality decisions. In the same vein, Rohlander (2014) claimed that effective teams are cohesive units of heterogeneous individuals. Indeed, the hallmark of the research group in 
this study was its ability to resolve any differences openly and amicably through dialogue. This fundamental cohesion is exemplified by the phrase "Unity was our strength" in the passage quoted above. The last sentence of the excerpt, meanwhile, indicates that the research group understood its mission. This finding resonates with Werner's (2014) assertion that it is important for a team to clarify its goal and purpose.

\section{Developing Rules of Engagement}

The research group's rules of engagement were a set of principles and values that defined their desired attitudes and behaviours:

Fellow team members, I propose that before we embark on this interesting journey, we should have rules that will guide our operations and engagement for the duration of this project. We need order. (Principal, p. 18)

Looking back, noting that we came from different backgrounds, culturally and otherwise, it is amazing that we could work so well together. Unbelievable! The rules that we adopted at the beginning served us well. Pity that this family that met religiously for months has to come to an end. $(D H, p .7)$

According to Werner (2014), rules are important for team formation. These excerpts confirm that the operating rules adopted by the team at the start of the project were vital for its cohesion (Rohlander, 2014) given that they helped team members to develop close relationships that engendered camaraderie.

\section{Collaborative Planning}

PAR conceptualises the research activity as a collaborative and negotiated process in which the tone and direction of the research belong equally to participants (Jacobs, 2018). Collaborative planning involves developing a shared vision, conducting a SWOT analysis, prioritising needs, and developing an implementation plan, each of which I will explore below.

\section{Developing a Shared Vision}

McGrawth and Bates (2013) asserted that every team must have a vision. In this study, the shared vision of the research group was encapsulated in its perceived shared destination, as the following excerpts demonstrate:

Ladies and gentlemen, it is proper that we understand why we are here. If we miss this, we are going to engage in futile exercises. Our joint aim is to help the departmental heads to execute their managerial responsibilities effectively. This should be the goal that frames our discussions. (Principal, p. 25)

Colleagues, good day. We are almost there with our project. It would not have been easier had we not had something that we were working towards. We were, and are, driven by this thing we want to achieve with our HODs. The commitment to achieve it has put us thus far and we are not willing to abandon the journey. Victory is beckoning. (Community development worker, p. 25)

Tang (2016) observed that a team is driven by the bigger picture, and the above passages affirm that it would not have made sense to assemble a research group without clarifying its vision. 
The above excerpts also highlight the relationship between a shared vision and the need for change and mobility: the group's shared vision stemmed from dissatisfaction with the status quo and aimed to realise a total overhaul of the $\mathrm{DHs}^{\prime}$ problematic practices. Mobility and transformation were therefore key features of the shared vision in this study. Furthermore, the group's shared vision set in motion activities that led to the inception and successful completion of the study. In the final analysis, the vision crystallised the group's energies towards a single focal point (Abib-Pech, 2013). Much like the shared rules of engagement, the shared vision was important for bringing the research group together into a cohesive team.

The following excerpt captures a DH's joy at being involved in the project:

I am happy that as departmental heads we are part of this collaborative planning. Things that affect us are done without us. This project is a testimony to the adage, "nothing about us without us." At least, our voices will matter now. (DH, p. 13)

These words capture the importance of actively involving those who are the subject of the research to develop solutions to challenges. The World Health Organization (2002) called for people to be actively and genuinely involved in defining issues of concern to them. Similarly, Loewenson et al. (2014) advised that those affected by a problem become the primary source of information and the primary actors in generating, validating, and using knowledge for action. However, DHs are often excluded from discussions and planning regarding issues that affect them directly, according to the participants in this group. Therefore, the inclusion of DHs was a shift from a "service-led system where people are fitted into a pattern of provision developed historically, to user-led or user-centered services" (McEvoy et al., 2019). Because the DHs were included in the study that sought to improve their practice, they took ownership of the study and remained committed to it. The attendance registers compiled during the eight sessions that spanned six months show that all $16 \mathrm{DHs}$ attended all the sessions.

\section{Conducting a SWOT Analysis}

A SWOT analysis is the best-known tool for evaluating an environment (Achadinha, 2016), and it is often the first step in planning (Booysen, 2015). The research group conducted a SWOT analysis by gathering information on the effectiveness of the DHs. The group scanned the internal and external environments and interpreted the information that was generated, as is captured in the excerpts below:

For a start, why don't we isolate areas where our HODs are strong? Then, identify their Achilles' heels. By this, I mean their challenges and areas where they are found wanting. (Principal, p. 23)

I am elated that we scanned the internal and external environments to identify our strengths, weaknesses, including opportunities and threats. This has given us, as HODs, a holistic picture of our competence. (DH, p. 67)

A SWOT analysis is not just about listing strengths, weaknesses, opportunities, and threats. Rather, it involves asking questions about these factors and formulating clear strategies in relation to them (Werner, 2014). In this study, the SWOT analysis was guided by the following questions: "Is there a need for a strategy?" "Which conditions would be propitious for the strategy?" "Which inherent threats might militate against the strategy?" "Which mechanisms should be built into the strategy to mitigate these threats?" "What evidence would bear proof of the effectiveness of strategy?" These questions gave rise to a comprehensive analysis that in turn became a strong basis for improving the 
performance of the DHs. Therefore, the SWOT analysis facilitated the identification of both the nature and the causes of existing deficiencies and limitations (Kiley, 2014).

During this exercise, the research group identified the nine main challenges that hampered the management performances of DHs. These were planning, holding meetings, holding accountability sessions, monitoring, communication, managing time, managing finances, managing departmental assets, and balancing professional and private activities.

\title{
Prioritising Needs
}

While nine main challenges were identified through the SWOT analysis, the prioritisation of these challenges emerged as another important activity in collaborative planning:

\begin{abstract}
Good people, we cannot do everything. It will do this meeting good if we focus on few things rather than doing everything. We need to be realistic. Let us identify few things for improvement. (DH, p. 31)

I am happy that my suggestion to rank the priorities in order of their importance was accepted. We managed to prioritize planning, meetings, communication, accountability, and monitoring. I feel that if HODs can improve in these five areas of their needs, the four other areas which fell by the wayside shall be automatically improved. The nominal group technique was helpful. (DH, p. 20)
\end{abstract}

The excerpts above indicate that the research group members applied their minds to the nine main needs of the DHs and prioritised five needs that they felt deserved attention because of their relative importance (Firesmith, 2004). The group's successful prioritisation process is congruent with McChesney et al.'s (2012) assertion that it is wise to focus on a few core aspects of a problem, rather than attempting to improve everything at once. Dealing with too many issues can negatively affect a team's focus. The decision about which needs to prioritise was not haphazard because we used the nominal group technique (Werner, 2014), which democratised the prioritisation process. Huntjens et al. (2011) added that prioritisation minimises domination and marginalisation within groups. In this study, the nominal group technique increased the participation of all during the identification of challenges.

\section{Developing an Implementation Plan}

A strategy might make sense when it is conceived, but an implementation plan is crucial to ensure that the strategy is adequately executed. The research group arrived at this conclusion organically:

It will make sense for us if we have a plan. This plan will indicate to us what should be done, when, and by whom. Without it, we will be like people groping in the dark looking for a black cat. (DH, p. 31)

At long last we have finalised our blueprint and roadmap today. We know what to do when and how. This is great. The different activities, milestones, and their related time-horizons are clear. All that is left is to implement the ideas in our documents to make them alive. This holds true for our HODs, who should action the activities that are aimed at improving their practice. Having said this, I must confess that doing the plan was quite demanding, yet possible, because of the SWOT analysis we had done. (Principal, p. 29) 
Lazenby (2016) argued that planning gives direction and allays uncertainties and anxieties -a sentiment that is evident in the hopeful tone of the above passages.

The implementation plan drawn up by the research group consisted of priorities that needed to be addressed. Each priority included deliverable activities with clear timelines that which were assigned to specific individuals according to their expertise. In this sense, the implementation plan specified both the ends and the means (Lazenby, 2016). In other words, it indicated what should be done and how/by whom it should be done. It was therefore a detailed plan of who did what, when, and how (Johnson \& Christensen, 2014). PAR acknowledges that some individuals in the research may be tasked with leading certain phases of the research enterprise at particular points. In this study, the resources needed to address a specific priority were allocated and success indicators were agreed upon as the basis for evaluation during the monthly reflection meetings.

Cant (2010) identified poor implementation of a strategy as the Achilles' heel of many organisations. Similarly, Booysen (2015) warned that planning becomes futile in the absence of implementation. With this in mind, the plan developed by the research group in this study was carefully implemented:

Practical steps were given, including good practices locally, continentally, and internationally. Mind blowing. Of importance is the fact that this is our seventh meeting and all activities before this meeting took place as scheduled, without any deviation. I want to unashamedly report to this meeting as a principal that the four departmental heads have implemented the guidelines on planning, communicating, monitoring, meetings, and accountability to the letter, though in some instance with modifications due to the unique nature of our school, and it is beginning to yield dividends. (Principal, p. 21)

Looking back, this project became successful because everything we agreed on was fully implemented. Kudos to our hardworking HODs who implemented almost everything they learned from all the workshops. (Deputy principal, p. 36)

I have so far held one departmental meeting, four subject meetings, and three developmental meetings. Teachers are told in advance what to prepare for each meeting and the departmental year plan. During the departmental meeting, I present my term plan to educators. I allowed them to make inputs during these meetings. They are beginning to own up to our programs and decisions we take during meetings. I have noted that I, too, have changed. I talk less and listen more, and this is helping me to understand teachers more clearly and in context. I listen to understand, but not to hear. Through listening, I am able to gather a lot of information around issues, and this contributes to making informed decisions. Notices for meetings are issued at least five days before meetings are held, thereby allowing teachers in my department to make inputs on agenda items and to prepare themselves for the meetings. (DH, p. 28)

In my department, we hold accountability sessions during the second week of every new school term. During these sessions, teachers give reasons for performance of learners in subjects they teach. I also account to the teachers for failing to provide them with requisite resources. In one meeting, a teacher wanted to know why mathematics books for Grade 10 have not yet been procured when the decision to do so was taken four months ago. Accounting is upwards, downwards, and horizontal. (DH, p. 27)

I have verified and brought evidence to this meeting. I need to share with you how they monitor and control the work of the teachers and learners. They have programmes of monitoring, implying that teachers know when they are going to be monitored. 
Monitoring is done weekly. During this monitoring, five things are looked into. Firstly, compliance with the annual teaching plan. Secondly, they monitor the quality of assessment activities. Thirdly, they check the frequency of assessment activities. Fourthly, whether activities are marked. Fifthly, the writing of correct corrections by learners. Curriculum coverage has improved a lot because of this type of monitoring by the DHs. (Deputy principal, 16)

As is evident from the above, the research group implemented its plan eagerly and efficiently. PAR demands that a research group acts on its plans (Kemmis \& McTaggart, 2005) and, indeed, individuals in the group who were assigned specific responsibilities fulfilled them diligently. This outcome may be attributable to the inspirational vision and commitment shared by the group. Similarly, Johnson et al. (2017) found that ownership and commitment play a vital role in the successful implementation of plans. It can therefore be argued that commitment is the fuel that enables teams to remain steadfast in pursuit of their goals (Johnson et al., 2017).

\section{Developmental Sessions}

Professional development is important for teachers because it ensures that their practice does not calcify. Workshops were a constant feature of the conversations that took place among the research group, and were affirmed as a necessary component of management performance strategy:

I want to confess that I remain unhappy with workshops that I attended before the start of this project. They were misplaced, compared to the several that we attended during the duration of this period. These were very relevant and enriched our practices as departmental heads. The knowledge and skills have given us the confidence we did not have before. This is the way to go. (DH, p. 20)

For every area wherein HODs are weak, we need to organize workshops for them. I believe that they are the tried and tested form of development. They should be real workshops and not mere talk shops, if they are to be meaningful for our HODs. (DH, p. 21)

Workshops have become the staple of teacher-development initiatives. The 2009 Teaching and Learning International Survey found that workshops were second (81\%) only to informal dialogue (93\%) in terms of efficacy in improving teaching (Organisation for Economic Co-operation and Development, 2009). However, Mizzel (2010) observed that poorly conceived workshops can leave people feeling disgruntled. For example, workshops that are too theoretical and general can have the effect of casting teachers as passive recipients of knowledge rather than co-generators of knowledge (Wood \& Goba, 2011), thereby perpetuating Freire's (1993) notion of banking education, because this kind of approach disavows teachers' prior learning and rich, lived professional experiences (McNiff, 2016). Workshops need to earn the commitment of participants and this can only happen if participants are involved in decision-making processes regarding their development. When people are fully involved, ownership emerges, which spawns commitment. Commitment, in turn, yields sustainability (Wood \& Zuber-Skerritt, 2013).

After a series of workshops carried out in line with the group's implementation plan, one member of the group reported:

The six workshops were informative; we learnt a lot. They were for us and about us. Do you still remember that all workshops started at 14:00 and were supposed to adjourn at 16:00? What happened? The workshops on meetings and monitoring, for example, were adjourned at 16:45 and 17:00, respectively. The discussions were lively and the level of 
participation in both was unprecedented. Very enriching. I want to report to this meeting three things. Firstly, meetings are the order of the day at my school. Teachers in my school refer to their DHs as the "democrats." They are humble, respectful, and listen a lot. They give teachers and learners hope. Secondly, the school culture has improved, due to the supervisory roles of the DHs. The third one excites me most. Our school, which has always been a perennial underperformer, performed well in the matric exams. We are no longer an underperforming school. (DH, p. 30)

This statement highlights the importance of workshops and, more importantly, how they are conceived. Participants identified with the contents of the workshops, which were based on challenges that they themselves had prioritised. Evidently, Tsayang et al.'s (2010) recommendation that workshops be based on the developmental needs of teachers was borne out during the workshops conducted for this study.

\section{Reflecting}

Reflection was a defining feature of this study, as the two excerpts below show:

Fellow participants, the first meeting that I held in my department failed to yield the projected results. The meeting failed to come up with a template for the subjectimprovement plan. Looking back, I think I never allowed room for my colleagues to air their views and make inputs. I am looking forward to my next meeting next week. (DH, p. 28)

I had a similar situation. Realising that teachers showed no interest, I adjourned the meeting for five minutes and when we resumed, I popped the questions: "Colleagues, how should we approach this?" "How best can we do this?" The response and inputs were overwhelming. (DH, p. 28)

The first excerpt exemplifies the kind of reflection that happens post practice. The second, meanwhile, reveals reflection happening mid practice, with the $\mathrm{DH}$ in question reflecting and changing course on the spot. Planning, acting on plans, and reflecting on actions are key features of PAR (Kemmis \& McTaggart, 2005).

Reflection is a tool that enhances continuous professional development. Helyer (2015) posited that reflection becomes effective when it is done with others; ideas are shared that may result in new ways of doing things. Consequently, collaborative reflection deepens self-awareness (Wood \& ZuberSkerritt, 2013). In this study, awareness helped people challenge assumptions, resulting in the assimilation and adoption of fresh insights and perspectives. The transformative potential of PAR was also evident. DHs, who before the study were cast as autocrats, were by the end of it labelled "democrats," as corroborated by the following excerpt:

The HODs at my school are now humble, respectful, and listen a lot. Before meetings are called, they now [emphasis added] invite inputs on agenda items from teachers in the departments. They are amenable to ideas of teachers and some of these inputs are implemented. (Deputy principal, p. 22)

As democrats, DHs afforded the teachers in their departments the chance to participate in decisionmaking processes, which would have had an empowering effect (Addi-Raccah, 2009). Importantly, participation promotes social justice by eliminating domination and marginalisation (Bell, 2007; 
Theoharis, 2007). By treating teachers as equal partners and with respect, DHs are more likely to uphold teachers' dignity.

\section{Refining the Implementation Plan}

The research group reflected on the change process and made revisions where necessary. Certain tactics were refined in line with particular contexts and developments, leading to an overhaul, at times, of the implementation plan. Plans should not be cast in stone but should instead be flexible for adaptation. According to Booysen (2015), weaker areas of implementation should be tweaked to improve performance in the future. Tweaking and adjustments are possible in PAR because the framework is not rigid and "linear," but "emergent and unpredictable," and ultimately "peoplecentered" (Wood \& Zuber-Skerritt, 2013, p. 2).

\section{Conclusion}

From the above discussion, the following conclusions are made: firstly, people appear to respond extremely well to programmes in which they are part of decision-making processes. This favourable response is further buttressed when a programme addresses participants' specific developmental needs.

Another conclusion is drawn from my personal reflections. The research process confirmed that the success or failure of a PAR study rests on the ability of the researcher to descend from their proverbial ivory tower and see themselves as an equal partner in the research group. As such, the researcher must collaboratively set objectives with members of the research group and spend more time listening. Yet they must also act-when necessary-as a critical friend who invites the entire team to take leaps into uncharted territory. Overall, the researcher should create an atmosphere in which the untapped reservoir of experience, knowledge, and skills in the research group can emerge.

Traditional research approaches seem to not be effective in ameliorating the plight of DHs in South African primary and secondary schools. PAR, embedded in the CER paradigm, was operationalised in this study as an antidote to the professional malady plaguing DHs. The result was a strategy that transformed DHs into effective practitioners whose practice was rooted in social justice principles. They became effective because they were fully immersed in collective efforts to improve their management practices. This outcome illustrates the ontological and epistemological potency of PAR as a practice-enhancing process.

\section{References}

Abib-Pech, M. (2013). The Financial Times guides to leadership: How to lead effectively and get results. Pearson.

Achadinha, N. (2016). The organisational environment. In J. A. A Lazenby (Ed.), General management (pp. 43-69). van Schaik.

Addi-Raccah, A. (2009). Between teacher's empowerment and supervision: A comparison of school leaders in the 1990s and 2000s. Management in Education, 23(4), 161-167. https://doi.org/10.1177/0892020609344018

Asghar, J. (2013). Critical paradigm: A preamble for novice researchers. Life Science Journal, 10(4), 3121-3127.

https://www.researchgate.net/publication/260675135 Critical Paradigm A Preamble for Novi ce Researchers 
Bell, L. A. (2007). Theoretical foundations for social justice education. In M. Adams et al. (Eds.), Teaching for diversity and social justice (2nd ed., pp. 1-14). Routledge.

Benedict, E. (2016). Contemporary management issues. In J. A. A. Lazenby (Ed.), General management (pp. 307-333). van Schaik.

Bergold, J., \& Thomas, S. (2012). Participatory research methods: A methodological approach in motion. Forum: Qualitative Social Research, 13(4), 191-122. https://www.qualitativeresearch.net/index.php/fqs/article/view/1801/3334

Boonyuen, S., Charungkaittikul, S., \& Ratana-ubol, A. (2016). Integrating transformative learning and action learning approaches to enhance ethical leadership for supervisors in the hotel business. SHS Web of Conferences, 26, 1-5. http://doi.org/10.1051/shsconf/20162601136

Booysen, K. (2015). Dynamics of entrepreneurship. Juta.

Brydon-Miller, M. (2013). Ethics and action research: Deepening our commitment to principles of social justice and redefining systems of democratic practice. In H. Bradbury-Huang \& P. Reason (Eds.), The SAGE handbook of action research: Participative enquiry and practice (2nd ed., pp. 199210). SAGE.

Buskens, I. (2011). The free attitude interview. Free Attitude Interview Manual, 1, 1 -6. https://issuu.com/gracenetwork/docs/fai final

Cameron, C., \& Singh, M. D. (2013). Nursing research in Canada: Methods, critical appraisal, and utilization (3rd Canadian ed.). Elsevier.

Campbell, C. (2014). Community mobilisation in the 21st century: Updating our theory of social change. Journal of Health Psychology, 19(1), 46-59. https://doi.org/10.1177/135910531350

Cant, M. (2010). Marketing: An introduction. Juta.

Carr, W., \& Kemmis, S. (1986). Becoming critical. Falmer Press.

Cho, Y. (2013). What is action learning? Components, types, processes, issues, and research agendas. Learning and Performance Quarterly, 1(4), 11. https://www.researchgate.net/publication/283794420

Cho, Y., \& Bong, H. C. (2013). Trends and issues in action learning practices: Lessons from South Korea. Routledge.

Cho, Y., \& Egan, T. M. (2010). The state of the art of action learning research. Advances in Developing Human Resources, 12(2), 163-180. http://doi.org/10.1177/1523422310367881

Dworski-Riggs, D., \& Langehout, R. D. (2010). Elucidating the power in empowerment and the participation in participatory action research: A story about research team and elementary school change. American Journal of Community Psychology, 45(3/4), 215-230. https://doi.org/10.1007/s10464-010-9306-0

Eruera, M. (2010). Ma te whanau te huarahi motuhake: Whanau participatory action research groups. MAI Review, 3. https://whanauoraresearch.co.nz/wp-content/uploads/formidable/Ma-teWhanau-te-Huarahi-Motuhake.pdf

Fard, H. D. (2012). Research paradigms in public administration. International Journal of Humanities, 19(4),

55-108. https://citeseerx.ist.psu.edu/viewdoc/download?doi=10.1.1.991.5975\&rep=rep1\&type=pdf

Firesmith, D. (2004). Prioritizing requirements. Journal of Objective Technology, 3(8), 35-47. http://doi.org/10.5381/jot.2004.3.8.c4

Freire, P. (1993). Pedagogy of the oppressed. Penguin. 
Helyer, P. (2015). Learning through reflection: The critical role in work-based learning (WBL). Journal of Work-Applied Learning, 7(1), 15-27. https://doi.org/10.1108/JWAM-10-2015-003

Herr, K., \& Anderson, G. L. (2015). The action research dissertation: A guide for students and faculty (2nd ed.). SAGE.

Huntjens, P., Termeer, C., Eshuis, J., \& van Buuren, M. V. (2011). Collaborative action research for the governance of climate adaptation: Foundations, conditions and pitfalls. Wageningen University \& Research. https://library.wur.nl/WebQuery/wurpubs/406492

Jacobs, S. D. (2018). A history and analysis of the evolution of action and participatory action research. Canadian Journal of Action Research, 19(3), 34-52. https://doi.org/10.33524/ciar.v19i3.412

Johnson, R. B., \& Christensen, L. (2014). Educational research: Quantitative, qualitative and mixed methods approaches (5th ed.). SAGE.

Johnson, A., Lefort, F., \& Tesvic, J. (2017). Secrets of successful change implementation. McKinsey. https://www.mckinsey.com/business-functions/operations/our-insights/secrets-of-successfulchange-implementation\#

Jordan, S. (2008). Participatory action research. In L. M. Given (Ed.), The SAGE encyclopedia of qualitative research methods (pp. 601-604). SAGE.

Kelliher, F., \& Byrne, S. (2018). The thinking behind the action (learning): Reflections on the design and delivery of an executive management program. Journal of Work-Applied Management, 10(1), 3549. http://doi.org/10.1108/JWAM-05-2018-0010

Kemmis, S., \& McTaggart, R. (2005). Participatory action research: Communicative action and the public sphere. In N. K. Denzin \& Y. Lincoln (Eds.), The SAGE handbook of qualitative research (3rd ed., pp. 559-603). SAGE.

Kemmis, S., McTaggart, R., \& Nixon, R. (2014). The action research planner: Doing critical participatory action research. Springer. http://doi.org/10.1007/978-981-4560-67-2

Kiley, J. (2014). Workplace learning. In Z. Bergh (Ed.), Introduction to work psychology (pp. 161-195). Oxford University Press.

Kivunja, C., \& Kuyini, A.B. (2017). Understanding and applying research paradigms in educational contexts. International Journal of Higher Education, 6(5), 26-41.

Lazenby, K. (2016). Planning. In J. A. A. Lazenby (Ed.), General management (pp. 93-114). van Schaik.

Lippman, S. A. (2013). Conceptualizing community mobilization for HIV prevention: Implications for HIV prevention programming in the African context. PLoS one, 8(10), e78208. https://doi:org/10.1371/journal.pone.0078208

Loewenson, R., Laurell, A. C., Hogstedt, C., D’Ambruoso, L., \& Shroff, Z. (2014). Participatory action research in health systems: A methods reader. EQUINET.

Makombe, G. (2017). An expose of the relationship between paradigm, method and design in research. The qualitative report, 22(12), 3363-3382. https://doi:org/10.46743/2160-3715/2017.3054

Malloy, N. C. (2017). The heads of department's leadership role in mathematics teaching and learning in three South African schools in Pinetown district [Master's dissertation, University of KwaZuluNatal]. University of KwaZulu-Natal, ResearchSpace. http://hdl.handle.net/10413/15427

Marquardt, M., \& Banks, S. (2010). Theory to practice: Action learning. Advances in developing human resource, 12(2), 159-162.

McChesney, C., Covey, S., \& Huling, J. (2012). The four disciplines of execution: Achieving your wildly important goals. Simon \& Schuster. 
McEvoy, R., Tierney, E., \& MacFarlane, A. (2019). "Participation is integral": Understanding the levers and barriers to the implementation of community participation in primary healthcare: A qualitative study using normalization process theory. BMC Health Research, 19, 515-528. https://doi.org/10.1186/s12913-019-4331-7

McGrawth, J., \& Bates, B. (2013). The little management book of big theories and how to use them. Pearson.

McNiff, J. (2016). You and your action research project (4th ed.). Routledge.

Mizzel, H. (2010). Why professional development matters. Learning Forward. https://learningforward.org/wp-content/uploads/2017/08/professional-developmentmatters.pdf

Nhlapo, J. V. (2014). Strategy to enhance the management performance of heads of departments at schools [Unpublished doctoral thesis]. University of the Free State.

Organisation for Economic Co-operation and Development (2009). Creating effective teaching and learning environment: First results from the Teaching and Learning international survey. https://www.oecd.org/education/school/creatingeffectiveteachingandlearningenvironmentsfirst resultsfromtalis.htm

Rehman, A. A., \& Alharthi, K. (2016). An introduction to research paradigms. International Journal of Educational Investigations, 3(8), 51-59. http://www.ijeionline.com/attachments/article/57/IJEI.Vol.3.No.8.05.pdf

Revans, R. (2011). ABC of action learning. Gower.

Reynolds, M. (2011). Reflective practice: Origins and interpretations. Action Learning: Research and Practice, 8, 5-13. https://doi.org/10.1080/14767333.2011.549321

Rohlander, D. (2014). Management skills. Alpha.

Tang, A. (2016). Be a great manager-now! Pearson.

Tedrow, C. E., Virginia, A., Zelaya, C. E., \& Celentano, D. (2012). No "magic bullet": Exploring community mobilization strategies used in a multi-side community based randomized controlled trial: Project Accept (HPTN 043). AIDS and Behavior, 16(5), 1217-1226. http://doi:10.1007/s10461-011-0009-9

Theoharis, G. (2007). Social justice, educational leaders and resistance: Towards a theory of social justice leadership. Educational Administration Quarterly, 43(2), 221-258. https://doi.org/10.1177/0013161X06293717

Thornton, K., \& Yoong, P. (2011). The role of the blended action learning facilitator: An enabler of learning and a trusted inquisitor. Action Learning: Research and Practice, 8, 129-146. https://doi.org/10.1080/14767333.2011.581021

Tsayang, G., Monyatsi, P., Bulawa, P., \& Mhozya, C. (2010). An evaluation of the primary school management development project in Botswana. Journal for Social Sciences, 23(2), 111-121. https://doi.org/10.1080/09718923.2010.11892819

Van Der Voort, G., \& Wood, L. (2014). Assisting school management teams to construct their school improvements plans: An action learning approach. South African Journal of Education, 34(3), 1-7. https://doi.org/10.15700/201409161046

Van Der Voort, G., \& Wood, L. (2016). An action-learning model to assist circuit teams to support school management teams towards whole-school development. South African Journal of Education, 36(4), 1-11. http://doi.org/10.15700/saje.v36n4a1327

Van Dijk, T. A. (2006). Discourse and manipulation. Society and Discourse, 17(2), 359-383. https://doi.org/10.1177/0957926506060250 
Werner, A. (2014). Social processes in the workplace. In Bergh, Z. (Ed.), Introduction to work psychology (pp. 226-259). Oxford University Press.

Wessels, E., \& Wood, L. (2019). Fostering teachers' experiences of well-being: A participatory action learning and action research approach. South African Journal of Education, 39(1), 1-10. http://doi.org/10.15700/saje.v39n1a1619

World Health Organization. (2002). Community participation in local health and sustainable development: Approaches and techniques. https://apps.who.int/iris/bitstream/handle/10665/107341/E78652.pdf? sequence=1\&isAllowed= y

Wood, L., \& Goba, L. (2011). Care and support of orphaned and vulnerable learners at schools. South African Journal of Education, 31(2), 275-290. https://www.ajol.info/index.php/saje/article/view/66461/54185

Wood, L., \& Zuber-Skerritt, O. (2013). PALAR as a methodology for community engagement by faculties of education. South African Journal of Education, 33(4), 1-10. https://www.ajol.info/index.php/saje/article/view/97287/86601

Yosso, T. J. (2005). Whose culture has capital? A critical race theory of community cultural wealth. Ethnicity and Education, 8(1), 69-91. https://doi.org/10.1080/1361332052000341006 